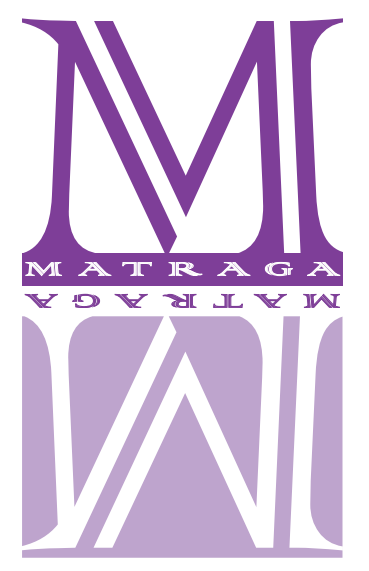

\title{
Narrativas de um real em ruínas: dois momentos da literatura portuguesa pós-25 de abri|*
}

\author{
Roberta Guimarães Franco \\ Universidade Federal de Minas Gerais, Brasil
}

https://orcid.org/0000-0003-0098-2481

Karol Sousa Bernardes

Universidade Federal de Lavras, Brasil

https://orcid.org/0000-0002-4965-8837

\begin{abstract}
RESUMO
Diversos críticos têm apontado para uma espécie de recuperação do realismo na narrativa portuguesa contemporânea, especialmente naquela produzida após o fim do Estado Novo e a consequente descolonização dos territórios africanos. Se o período entre as décadas de 30 e 70 do século XX foi marcado por silenciamentos e censura, após a Revolução dos Cravos, em 1974, vemos o surgimento de vários romances que trazem principalmente o tema da Guerra Colonial como foco. Por outro lado, alguns desdobramentos desse contexto, como a condição dos retornados na sociedade portuguesa, parecem surgir somente em um momento posterior, sobretudo a partir da década de 90, e vem ganhando novo fôlego no século XXI. Nesse sentido, este artigo propõe-se a realizar uma análise do que identificamos como dois momentos de abordagem do real na literatura portuguesa contemporânea: o primeiro, voltado para os anos imediatamente após a Revolução dos Cravos e observando um foco maior no cenário da Guerra Colonial, a partir das obras Os Cus de Judas (1979), Autópsia de um mar de ruínas (1984), A Costa dos Murmúrios (1988) e Jornada de África (1989); e o segundo recorte a partir do final do século XX e até o início da segunda década do século XXI, com as obras O esplendor de Portugal (1997), Caderno de memórias coloniais (2009) e O retorno (2012), que já trazem uma atenção especial à situação dos retornados. Em comum, os dois momentos acabam por identificar uma realidade de ruína, especialmente do imaginário criado pelos discursos do Estado Novo.
\end{abstract}

PALAVRAS-CHAVE: Literatura Portuguesa Contemporânea; Guerra Colonial; Retornados.

\section{Narratives of a real in ruins: two moments of post-April 25 Portuguese literature}

\section{ABSTRACT}

Several critics have pointed to a type of recovery of realism in the contemporary Portuguese narrative, especially that produced after the end of the "Estado Novo" and the consequent decolonization of African territories. If the period between the 30s and 70s in the 20th century was marked by silence and censorship, after the "Revolução dos Cravos" in 1974, we see the emergence of several novels that mainly bring the theme of the Colonial War as a focus. In contrast, some developments of this context, such as the condition of

\footnotetext{
* Este artigo é um dos resultados do projeto "Poder e silêncio(s): a pós-colonialidade entre o discurso oficial e a criação ficcional", financiado pela FAPEMIG.
} 
the returnees in Portuguese society, seem to arise only later, especially from the 1990s, and they have been gaining new breath in the 21st century. In this sense, this article proposes to analyze what we identify as two moments of tackling the real in contemporary Portuguese literature: the first one, which is focused on the years immediately after the Carnation Revolution and which has a greater focus on the Colonial War scene, in the books Os Cus de Judas (1979), Autópsia de um mar de ruínas (1984), A Costa dos Murmúrios (1988) and Jornada de África (1989); and the second moment, from the end of the 20th century until the beginning of the second decade of the 21st century, in the books $O$ esplendor de Portugal (1997), Caderno de memórias coloniais (2009) and O retorno (2012), that already bring special attention to the situation of returnees. In common, the two moments end up identifying a reality of ruins, especially the imaginary created by the "Estado Novo".

KEYWORDS: Contemporary Portuguese Literature; Colonial War; Returnees.

\section{Introdução}

Diversos críticos da literatura portuguesa contemporânea, dentre eles Miguel Real (2012) e João Barrento (2016), apontam uma espécie de ressurgimento do realismo, especialmente a partir das últimas décadas do século XX. Real afirma que a “[...] partir da década de 80, assistiu-se à lenta recuperação do realismo, dotado de novas qualidades, incorporando o esteticismo e o desconstrucionismo narrativos das duas décadas anteriores, estatuindo-se hoje, de novo, como estilo dominante do romance português" (2012, p. 17). Ainda que Barrento reconheça que, devido à quantidade de escritores e vertentes diversas, seja difícil pensar a literatura portuguesa contemporânea como uma produção formada por uma "'rua principal' e 'vários atalhos secundários"” (2016, p. 12), ele destaca que "boa parte da literatura das últimas décadas se alimenta do que veio de Abril, já que se trata em muitos casos de uma escrita que foi elaborando uma visão literária da Revolução e das fases pós-Revolucionárias" (2016, p. 14). Nesse sentido, o vínculo da produção literária contemporânea com o 25 de abril de $1974^{1}$, mesmo não podendo ser classificado como um caminho principal do qual brotam várias vertentes, é um indicativo da presença do real em uma parte considerável dessa produção.

O tempo e a escrita que se configuram não só após a Revolução dos Cravos (1974), mas especialmente após os longos anos do Estado Novo Português (1933-1974) e sua política de autoritarismo, mostram-se como um novo momento de representação da própria ideia de nação. Se a censura e os discursos do governo conseguiram manter um imaginário do Império para a maior parte da população portuguesa, o contexto posterior à Guerra Colonial e às descolonizações trouxe, principalmente a partir da chegada dos "retornados" (portugueses e seus descendentes que voltavam das colônias africanas), uma compreensão do estado de decadência em que Portugal se encontrava.

\footnotetext{
1025 de abril de 1974, data em que ocorreu a Revolução dos Cravos em Portugal, marca o início da derrocada do Estado Novo Português, regime autoritário governado majoritariamente por António de Oliveira Salazar, entre 1933 e 1968 - motivo pelo qual o Estado Novo é também chamado de período Salazarista - e, posteriormente, por Marcelo Caetano, de 1968 a 1974.0 historiador Fernando Rosas (2018) caracteriza o regime como "nacional autoritário", além de antidemocrático, antiparlamentar e anticomunista. A Revolução dos Cravos é, portanto, reconhecida como início da transição para a redemocratização do país, bem como um impulso para o desfecho da Guerra Colonial, mantida desde o início da década de 1960 nos territórios africanos, que conseguiriam suas independências em 1975.
} 
A partir de finais da década de 1970, obras literárias, que apresentavam como tema a Guerra Colonial, começam a ser publicadas em Portugal. Muitos dos autores haviam atuado na guerra ou estiveram presentes nas ex-colônias durante o período do conflito (1961-1974). Assim, podemos considerar essas produções como uma forma de retomar o contexto de guerra que, durante o Estado Novo, foi silenciado, justamente por ser uma tentativa de expor os horrores do período. Entretanto, o que se observa é que as obras que abordam com maior enfoque a situação dos retornados surgem em um momento posterior, em uma época um pouco mais distanciada do fim do regime. Nesse sentido, buscamos realizar um percurso de análise de obras publicadas no contexto pós-25 de abril, entre os anos de 1979 e 2012, levando em consideração que estaríamos diante de dois momentos distintos de produção, ainda que no âmbito da literatura contemporânea, entre finais do século XX e início do século XXI. Para um primeiro momento, refletindo sobre as publicações logo após o fim do regime, foram escolhidos quatro romances: Os Cus de Judas (1979) de António Lobo Antunes, Autópsia de um mar de ruínas (1984) de João de Melo, A Costa dos Murmúrios (1988) de Lídia Jorge, e Jornada de África (1989) de Manuel Alegre. Para o que consideramos como um segundo momento, no qual a presença dos retornados se faz mais evidente, selecionamos as seguintes obras: O esplendor de Portugal (1997) também de Lobo Antunes, Caderno de memórias coloniais (2009) de Isabela Figueiredo, e O retorno (2012) de Dulce Maria Cardoso².

É importante destacar que o recorte do corpus literário foi pensado com o intuito de abarcar um período considerável de publicações que têm em comum o passado recente de Portugal. Trata-se de romances publicados ao longo de mais de trinta anos, sob perspectivas distintas e, na sua maioria, permeadas por um cunho autobiográfico, que demostram como o tema é ainda relevante e necessário para a sociedade portuguesa, tendo em vista que muitos desses temas são ainda silenciados, não mais pela existência de um regime ditatorial, mas pelos traumas. As narrativas que abordam esse período são também uma forma de se evocar o indizível e, assim, desconstruir muitos mitos e estereótipos reafirmados pelo Estado Novo português e que, de várias formas, ainda se fazem presentes na atualidade. Ao pensar os dois momentos de produção ao longo desses trinta anos - de 1979 a 1989 e de 1997 a 2012 -, pretendemos não só refletir sobre como a literatura revela realidades distintas daquela propagada pelo Estado Novo, expondo as ruínas de um país decadente, mas também sobre o caráter memorialístico e testemunhal desses romances.

\section{Pós-25 de abril: (des)construindo narrativas sobre Portugal}

A imagem de Portugal como um país colonizador constituiu, ao longo dos séculos, um dos aspectos principais da história e da identidade portuguesas. O passado de Portugal era tido como "grandioso", principalmente pelas conquistas oriundas da expansão marítima. Como aponta

\footnotetext{
${ }_{2}$ Optou-se, para a escolha do corpus literário, pela repetição do autor António Lobo Antunes, tendo em vista que a proposta de análise aqui apresentada não está focada em uma questão geracional dos escritores, mas sim em dois momentos distintos de produção literária dentro do contexto contemporâneo. Nesse sentido, considerou-se relevante trazer duas obras do autor, já que as percepções sobre o real, em momentos distintos da sua própria produção, corroboram com a proposta do texto.
} 
Eduardo Lourenço (2016), os portugueses eram grandes "longe", fora do espaço que lhes cabia na Europa, ou seja, a maior parte do território português se encontrava nas colônias. Tendo em vista esses fatores, a colonização e os processos que a envolvem foram retomados e ressignificados pelo Estado Novo português, a fim de fomentar o caráter nacionalista da nação.

Na década de 1960, a imagem imperial de Portugal é abalada, visto que se iniciam as guerras coloniais no ultramar, que só tiveram fim em 1974. Esse ano também marcou o fim do Estado Novo e de Portugal como nação imperial, sendo, segundo Ribeiro (2003), o momento de regresso do país ao seu espaço europeu. À vista disso, podemos destacar que, nos anos posteriores ao 25 de abril de 1974, não houve tantos estudos historiográficos sobre o período do regime e da Guerra Colonial, instalando-se uma continuidade do silêncio na sociedade portuguesa, como assinala Roberta Guimarães Franco: “[...] o período de redemocratização do país, após a Revolução dos Cravos, momento em que se esperava uma profusão de vozes, acabou por demonstrar que os traumas e cicatrizes eram mais profundos" (FRANCO, 2018, p. 155).

Com o silenciamento presente nesse período posterior à Revolução dos Cravos, os portugueses que estiveram na Guerra Colonial, segundo Ribeiro (1998), foram os que deram o primeiro testemunho sobre esse contexto através da ficção, sobretudo a partir dos anos 1980. As narrativas dessa geração pós-25 de abril, como destaca Roberta Guimarães Franco, "ao apresentarem versões sobre os acontecimentos que ocorreram durante o Estado Novo e a Guerra Colonial, acabam por questionar, colocar em xeque, uma noção de identidade perpetuada por séculos, de um Portugal grande" (2018, p. 163).

Com base nesse cenário de ruínas, a literatura, através do testemunho e da memória como elementos de abordagem do real, pode colaborar para a reconstrução do processo histórico desse contexto, que, nos anos subsequentes à descolonização, não teve uma produção científica rigorosa que se dedicasse a investigá-lo - resultado, principalmente, do período de controle do regime salazarista. A partir dessas questões, foram selecionados os romances que compõem este primeiro momento, de 1979 e 1989.

Os autores das obras participaram da guerra ou estiveram presentes nas colônias africanas, o que marca uma proximidade das narrativas e o contexto histórico com as experiências vivenciadas por eles. Os Cus de Judas (1979), de António Lobo Antunes, apresenta um narrador-personagem médico, após a guerra em Angola, que conta suas experiências do período através de uma narrativa fragmentada e composta de memórias. Autópsia de um mar de ruínas (1984), de João de Melo, traz diferentes perspectivas sobre o contexto de Guerra Colonial, tanto por parte dos colonizadores quanto dos colonizados, fazendo a autópsia que o título já anuncia. A Costa dos Murmúrios (1988), de Lídia Jorge, apresenta o contexto de guerra em Moçambique a partir de uma perspectiva feminina, na voz de Eva Lopo, ao relatar de forma fragmentada, como flashes de memórias, os acontecimentos de sua vida durante o tempo da guerra. Por fim, Jornada de África (1989), de Manuel Alegre, traz, através de uma narrativa em terceira pessoa, a figura do alferes Sebastião, um adversário do regime salazarista e contrário à guerra, que vai servir ao exército português nos confrontos em Angola, traçando um paralelo entre o discurso nacional do Estado Novo e aquele pertencente aos séculos XVI-XVII, ligados ao sebastianismo. 
Os quatro romances inserem-se em um período de dez anos, o que nos possibilita análises mais amplas acerca desse contexto de guerra. Os dois primeiros apresentam um tom mais intimista e testemunhal da perspectiva dos soldados portugueses sobre a decadência em que se encontravam. O de Lídia Jorge traz uma perspectiva mais abrangente, indo além do espaço onde a guerra ocorria, explorando como o conflito afetava também outras parcelas da sociedade, neste caso, as mulheres que acompanhavam os soldados portugueses. Já a obra de Manuel Alegre traça um percurso que lança nosso olhar sobre os cenários de guerra e os discursos do regime enunciados nesses ambientes.

Diante dessas obras, é possível perceber um movimento de desconstrução de uma imagem mítica de Portugal, realimentada pelo Estado Novo, à introdução, via literatura, de um novo imaginário para o público leitor português: a crua realidade da Guerra Colonial, tão escondida e/ou camuflada pelos discursos em prol do Império. Eduardo Lourenço (2016) destaca que os portugueses viviam, sobretudo, em função de uma imagem irrealista de si mesmos e da nação. Essa perspectiva se estende aos discursos do Estado Novo, que propagavam uma versão muito distante da realidade vivenciada na Guerra Colonial, de modo que as informações eram sistematicamente selecionadas para atingir os objetivos do regime e passavam também pelo controle da censura. Até então, ainda segundo o filósofo, o sistema havia atingido um nível de "perfeição na matéria", com um intenso caráter nacionalista, como se não fosse possível aos portugueses contraporem a visão de grandiosidade que ele propunha. Entretanto, essa imagem começa a ruir com o decorrer da guerra, a princípio, a partir da perspectiva daqueles que foram convocados a enfrentá-la ou dos que a presenciaram estando nas colônias. Podemos analisar esse contraste de concepções nas obras, a começar por Os Cus de Judas: “[...] condenados ao consumo de jornais que a censura reduzia a louvores melancólicos ao relento de sacristia de província do Estado Novo, e jogados por fim na violência paranoica da guerra, ao som de marchas guerreiras e dos discursos heroicos dos que ficavam em Lisboa [...]" (ANTUNES, 2010, p. 100). O narrador expõe esse consumo dos jornais como uma forma de condenação ao terem que lidar com um conteúdo de exaltação do Estado Novo, enquanto ele e os soldados tinham que enfrentar a violência da guerra. Aqueles que ficaram no comando em Lisboa discursavam de modo corajoso sobre o combate, embora não enfrentassem realmente a guerra em África, lá "nos cus de Judas".

Em Autópsia de um mar de ruínas, observamos que certos fatos eram "amenizados" pela imprensa, como o número de portugueses mortos nos combates, configurando nas páginas dos jornais um número fictício, amenizando a percepção de gravidade na metrópole. Além disso, na narrativa, acompanhamos as angústias e medos desses soldados e a inconformidade com a situação na qual se encontravam. Entretanto, oficialmente, eram considerados "corajosos" ao morrerem "generosamente": "Os jornais de Lisboa dariam parcamente a notícia da sua morte, dois nomes por semana e só dois, para que nunca parecessem muitos; era certo e seguro que o ministro mandaria um telegrama de condolências à família, grande, grande é a nossa pátria porque tais filhos ela tem [...]" (MELO, 1984, p. 128).

Em A Costa dos Murmúrios, esse contraste se mostra de forma diferente. Dividida em duas partes, a obra começa com um conto não muito longo, Os Gafanhotos, em que acompanhamos o casamento entre Evita e Luís Alex, em Moçambique. Por meio da figura dos convidados é 
apresentado o lugar privilegiado e considerado superior dos portugueses em relação aos negros. Na segunda parte, a voz de Eva contando suas experiências se sobressai: mesmo em uma narrativa escrita em terceira pessoa, observamos como as informações chegavam até Eva de forma fragmentada, como notícias de que os guerrilheiros ocuparam os espaços do "inimigo" e "desinfestar a zona", e enfocavam na "independência branca", como se a guerra estivesse por acabar (JORGE, 2004, p. 206, p. 100 e p. 205, respectivamente).

Jornada de África apresenta diversos cenários: “coxos, manetas, paraplégicos. O resto ficou nas picadas, Angola é nossa, venham ver, há bocados de carne por aí, são pedaços de Portugal florindo algures no mato, sangue e merda, [...] Para Angola e em força, braços, pernas, mãos" (ALEGRE, 1989, p. 169); fazendo alusão à célebre frase de Salazar - "Para Angola rapidamente e em força" -, contrapõe todo o misticismo dos discursos do regime com os absurdos da guerra, como o número altíssimo de mortes. Assim, para que seja possível problematizar e analisar o período de Estado Novo e de Guerra Colonial, é preciso reconhecê-lo e não o silenciar. Entretanto, Lourenço evidencia que, mesmo após treze anos de guerra colonial e da queda do império, não houve nem o surgimento na consciência social de "um traumatismo profundo - análogo ao da perda da independência", nem "um repensamento em profundidade da totalidade da nossa imagem perante nós mesmos e no espelho do mundo" (2016, p. 54).

Ao contrário do que se esperaria, é como se, em um primeiro momento, os portugueses silenciassem esse contexto, aspecto presente nas quatro obras, o que pode ser analisado por duas perspectivas. A primeira é a negação da guerra, resultado dos traumas causados por ela e, com isso, a impossibilidade de narrar os acontecimentos, como já ressaltou Walter Benjamin, ao se referir à Primeira Guerra Mundial (2012, p. 214). Em Os Cus de Judas, o narrador, ao retornar da Guerra Colonial, afirma que "tudo é real menos a guerra que não existiu nunca: jamais houve colónias, nem fascismo, nem Salazar, nem Tarrafal, nem Pide, nem revolução, jamais houve, compreende, nada" (ANTUNES, 2010, p. 193-194). No mesmo sentido, em Jornada de África, é manifestado que "a guerra não existe, um dia vais ver que nunca existiu" (ALEGRE, 1989, p. 124).

A segunda perspectiva é a de não se poder falar que há guerra, no sentido de desconsiderá-la e, desse modo, não a assumir enquanto conflito real. Em Autópsia de um mar de ruínas, um dos narradores relata que "havia em lugar visível, na parede em frente da porta, uma inscrição em letras garrafais à qual muita gente apontava o dedo para obrigar a mudar de conversa e dizia: É PROIBIDO DIZER QUE HÁ GUERRA" (MELO, 1984, p. 46). Com isso, mesmo estando na guerra diariamente e vivenciando a sua realidade, os soldados não podiam dizer que ela estava acontecendo de fato. Esse aspecto também está presente em A Costa dos Murmúrios, não utilizando o termo "guerra". A desvalorização da palavra e, assim, a própria desconsideração do conflito - postura assumida pelo regime salazarista - era algo intencional para se amenizar e até ocultar o que realmente acontecia: "Percebia também que ninguém falava em guerra com seriedade. O que havia ao Norte era uma revolta e a resposta que se dava era uma contra-revolta. [...] Não guerra. [...] A desvalorização da palavra correspondia a uma atitude mental extremamente sábia e de intenso disfarce" (JORGE, 2004, p. 79).

Outro aspecto a ser considerado é a fragmentação causada pela guerra. Ribeiro (1998, p. 147) evidencia que "[...] as guerras coloniais não se podem avaliar somente pela fragmentação 
física e pelas mortes, mas também pelas fragmentações psíquicas [...]”, abordagem perceptível nas quatro obras. Em Lobo Antunes, Manuel Alegre e João de Melo há a representação dos impactos da realidade da guerra na vida dos soldados, e em Lídia Jorge observamos os abalos desse contexto, sobretudo na vida das mulheres dos soldados portugueses. Essa fragmentação psíquica se desenvolve, por exemplo em Os Cus de Judas, nos dias que parecem não passar: "Aí, durante um ano, morremos não a morte da guerra, que nos despovoa de repente a cabeça num estrondo fulminante, [...] mas a lenta, aflita, torturante agonia da espera, [...] a espera do cada vez mais improvável regresso, com a família e os amigos no aeroporto ou no cais" (ANTUNES, 2010, p. 129). Ocorre também na condição em que os soldados portugueses se encontravam, com o calor que os atormentava, a precariedade da alimentação, da água e do sono, como vemos em Autópsia de um mar de ruínas: "Queixavam-se da seborreia, dos piolhos e das bostelas, [...]; outros ainda [...] sentiam por dentro um animal de agonia, [...] uma infinita sensação de sede nas suas tórridas entranhas fumegantes" (MELO, 1984, p. 44). Em A Costa dos Murmúrios, podemos observar essa fragmentação psíquica através da condição do alferes Luís Alex após seu retorno da guerra e sua mudança de comportamento, que afeta também a esposa, Eva: "começou a chorar abertamente, e era espantoso como chorava e as lágrimas do noivo tombavam nos ilhós do bornal. Era a primeira vez que via Luís Alex chorar. Chorava com soluços e com gritos" (JORGE, 2004, p. 262).

É válido ressaltar, como aponta Seligmann-Silva (2008), que o testemunho se apresenta como uma forma de sobrevivência e, nesse contexto, ele é um modo de se conservarem vivas as memórias do período de guerra. A construção das narrativas se dá a partir de lembranças e de posicionamentos individuais dos personagens, que expressam diferentes perspectivas sobre a guerra, apresentando os contrastes que se podem estabelecer sobre ela e os discursos do Estado novo, e sobre os possíveis cenários que ela apresenta. Tendo em vista essa realidade de ruínas e o seu silenciamento, a literatura que reelabora o real de um passado recente, preenche as lacunas por meio da memória e do testemunho.

\section{Os retornados: a realidade do despertencimento}

Se a Guerra Colonial não foi suficiente para a realização de uma revisão efetiva do "destino mítico português", como já abordamos a partir de Eduardo Lourenço (2016, p. 60), e tampouco para que os portugueses se interrogassem sobre as prováveis consequências desse contexto, é também o filósofo que aponta a chegada dos retornados ${ }^{3}$ como marco que fará com que a sociedade comece a ter mais consciência dos impactos decorrentes do fim da Guerra e da descolonização, pois o povo português "que a sério nada conhecia do fabuloso e mágico império - só

\footnotetext{
${ }_{3}$ Fernando Pimenta Tavares (2017) defende que a melhor "classificação" seria a de deslocados, isto é, "pessoas que foram constrangidas a deixar as suas casas, mas que não cruzaram nenhuma fronteira internacional” (PIMENTA, 2017, p. 103). Neste artigo, usaremos tanto as classificações de retornados quanto de deslocados para nos referir às pessoas que saíram das ex-colônias com destino a Portugal no período de 1973 e 1976, visto que as obras selecionadas para análise utilizam o termo "retornado".
} 
tomará realmente consciência dos acontecimentos quando após as independências de Angola e Moçambique centenas de milhares de retornados invadem de súbito a pacífica e bonacheirona terra lusitana..." (LOURENÇO, 2016, p. 75).

De forma complementar à perspectiva de Lourenço, Margarida Calafate Ribeiro (2004, p. 26) destaca que "a guerra não estava só em África, como o antigo regime pretendia, e onde parece que o novo regime, saído do 25 de Abril, gostaria de a ter deixado, [...] mas ela vinha a bordo dos navios que regressavam ao cais". Essa afirmativa evidencia que a "guerra" continuaria, mas agora no processo de desconstrução da ideia de "império", além da reintegração dos deslocados em Portugal. Nesse sentido, é válido ressaltar que a compreensão dessa nova etapa da história de Portugal demorou para ser processada e ainda o é, como afirma Fernando Tavares Pimenta que "[...] o êxodo das minorias brancas das colónias portuguesas permanece um assunto pouco estudado, inclusivamente pelos historiadores que se debruçaram sobre a descolonização portuguesa [...]" (2017, p. 100).

Até mesmo a literatura publicada imediadamente após o 25 de abril não teve como foco a situação/condição dos retornados, visto que se voltou mais, como abordamos anteriormente, às questões referentes a realidade da Guerra Colonial. Por isso, consideramos a existência de um segundo momento pós- 25 de abril, em que a literatura portuguesa contemporânea trará os retornados como personagens de um drama de que se desdobra; não mais a guerra em si, mas a sequência do fim do Império. Aqui, o recorte compreenderá três obras publicadas entre 1997 e 2012.

O esplendor de Portugal (1997), de António Lobo Antunes, apresenta Carlos, Rui e Clarisse, irmãos obrigados a ir para Portugal após a Revolução, e Isilda, a mãe deles, que permanece em Angola mesmo com a Guerra Civil. O segundo livro é Caderno de memórias coloniais (2009), de Isabela Figueiredo, que traz uma narradora branca, filha de portugueses e nascida em Moçambique. Assim como os filhos de Isilda, ela é enviada pelos pais para a metrópole, com o agravamento do cenário de guerra. Por fim, O retorno (2012), de Dulce Maria Cardoso, narrado pelo adolescente Rui, nascido em Angola e obrigado, assim como os personagens dos outros dois livros, a ir para Portugal com a família para fugir da violência do contexto de guerra.

Com a Revolução dos Cravos em 1974, os conflitos, que nas colônias já duravam mais de uma década, são intensificados até as independências, em 1975, seguidos pelas guerras civis que eclodem nas novas nações. O cenário de violência e de medo pode ser observado nas três obras, a começar por O esplendor de Portugal, na voz de Isilda, que permaneceu em Angola: "Devia ter desconfiado que Angola acabou para mim quando o garoto bailundo com um saco de feijão roubado sob o braço, encostado ao celeiro sob a coronha do cabo, matou dezenas e dezenas de brancos em Luanda, em Salazar, no Dondo, [...]” (ANTUNES, 1999, p. 197). Em O retorno, Rui declara que "Os pretos não começaram logo logo a matar brancos a eito mas quando lhe tomaram o gosto não quiseram outra coisa e os brancos ainda foram embora mais depressa. A cidade foi ficando mais vazia de dia para dia" (CARDOSO, 2013, p. 33); e a narradora de Caderno de memórias coloniais conta que: "Tudo era possível nesse tempo sem lei repleto de campos de reeducação. Morrer sempre foi fácil naquela terra, antes ou depois" (FIGUEIREDO, 2019, p. 90). Esses três trechos apontam que o cenário nas ex-colônias deixou de ser favorável aos portugue- 
ses, e os romances mostram como as notícias sobre as famílias que haviam sido mortas e como o medo dos ataques se intensificava chegavam até os personagens.

Com base nesse contexto de violência, cada vez mais pessoas decidiram ir para Portugal. Contudo, esse processo de emigração, em um primeiro momento, não parecia ser, como aponta Rita Garcia (2011), uma prioridade do Governo português. De forma complementar a essa perspectiva, indicamos o que destaca Roberta Guimarães Franco (2019) sobre a falta de eficiência por parte do governo em lidar com as questões referentes a essas pessoas que chegavam ao país. Isso pode ser entendido, segundo a autora, como uma "má vontade" em recebê-las, como se o grande contingente de pessoas reafirmasse o fim do império português e Portugal se negasse a aceitar isso, visto que o colonialismo era um aspecto marcante e definidor de sua identidade.

A partir desse cenário, a concepção de "grande império", tão reafirmada pelo Estado Novo português, dá lugar a uma outra narrativa, de modo a possibilitar uma visão de Portugal não mais como um país que tem a missão de colonizar outros povos, mas como um país em crise em todos os níveis básicos. À vista desses aspectos, os três romances podem ser entendidos como um espaço para compreender e problematizar o contexto que foi vivenciado por muitos portugueses que sofreram as consequências dos períodos do Estado Novo e da Guerra Colonial.

No que se refere à viagem de ida para Portugal mais propriamente, havia a dificuldade de conseguir passagens, gerando uma espera de dias nos aeroportos por uma oportunidade de sair das ex-colônias, como aponta Garcia (2011). A autora também destaca que esse retorno ocorreu em um momento de crise econômica no país, agravada pela onerosidade da Guerra Colonial, o que dificultou ainda mais a eficácia do processo. Dessa forma, como ressalta Roberta Guimarães Franco (2019), a saída de África foi o primeiro obstáculo enfrentado, elemento abordado nas três obras, em Lobo Antunes: “[...] aguardando no aeroporto e no cais semanas e semanas, estendidos em cobertores, mantas, trouxas, por um avião ou um barco impossíveis, traficando entre nós, de papel e lápis na mão em negociações ridículas, moradias, propriedades, automóveis que não havia já [...]” (ANTUNES, 1999, p. 247); ou ainda em Dulce Maria Cardoso: "O aeroporto tão diferente do aeroporto das tardes de domingo em que o pai nos trazia para vermos os aviões, [...] nunca vi tanta gente junta, nunca vi uma confusão tão grande, tantas malas e tantos caixotes, tanto lixo, lixo, lixo e mais lixo" (CARDOSO, 2013, p. 59); bem como em Isabela Figueiredo: "1975, novembro. Voos da TAP esgotados há meses, para qualquer destino" (FIGUEIREDO, 2019, p. 119); e "O aeroporto estava cheio: barulhos de coisas e pessoas, cheiro a suor, ansiedade, medo, perda” (FIGUEIREDO, 2019, p. 130). Todos esses trechos demonstram o ambiente caótico da ida para Portugal, no qual o desespero para sair das ex-colônias aumentava. Isso se soma a uma espécie de insatisfação dos portugueses por deixarem a África, tendo somente incertezas do que os esperaria em Portugal.

Segundo Garcia (2011), após 1973, conforme o Censo de 1981, mais de meio milhão de pessoas chegaram a Portugal, vindas das ex-colônias. Para elas, o "sonho africano" havia acabado, dando lugar a um período de revolta e de grandes dificuldades de sobrevivência. Somado a isso, é válido ressaltar que essas pessoas foram classificadas como "retornadas", termo depreciativo e preconceituoso, como "portugueses de segunda", e "exploradores de negros, habituados à boa vida e servidos por um exército de criados domésticos" (GARCIA, 2012, n.p). Com a crise econô- 
mica em Portugal, os portugueses acabavam também por ver os retornados como "adversários dispostos a roubar-lhes trabalho, habitação e dinheiro" (GARCIA, 2012, n.p). Nesse sentido, os deslocados não tinham lugar nas ex-colôniais e também não eram acolhidos em Portugal.

Ao chegarem na antiga metrópole, os retornados eram incentivados a procurarem familiares que os pudessem ajudar. A narradora de Caderno de memórias coloniais, por exemplo, foi morar com a avó, transição difícil para uma vida muito diferente daquela experienciada em Moçambique: "Só nesse ano percebi o que o meu pai dizia quando explicava que não éramos pobres nem ricos, mas remediados. [...]. Ser pobre era ouvir a minha avó dizer que mais valia lavar roupa para fora do que estudar [...] Era viver num quarto cuja pequena janela dava para o galinheiro [...]" (FIGUEIREDO, 2019, p. 142).

Entretanto, muitos deslocados não tinham familiares a quem pudessem recorrer e ficaram dependentes da ajuda do Estado para conseguirem se estabelecer; sem a maioria de seus bens, eram alocados em hotéis e pensões, o que dificultava ainda mais o processo de transição, como foi o caso da família de Rui, em O retorno. Já em O esplendor de Portugal, os personagens Carlos, Rui e Clarisse não se estabeleceram em algum alojamento proporcionado pelo Estado e não possuíam familiares que os pudessem ajudar, mas conseguiram se estabelecer em um pequeno apartamento. Com base nos aspectos considerados, as três obras apresentam cenários que nos possibilitam compreender e analisar como foram os processos de emigração para Portugal e a dificuldade de integração dessas pessoas no país, com narrativas descentradas da noção de "império português".

A afirmativa "Então a metrópole afinal é isto" (CARDOSO, 2013, p. 65) marca a chegada de Rui e da família a Portugal. Esse sentimento de decepção e descontentamento em relação à antiga metrópole perpassa as três obras. Com o processo de colonização, havia a construção e a imposição de uma imagem idílica de Portugal, como expõe Eduardo Lourenço (2016), além de uma narrativa baseada no "mito imperial", como aponta Fernando Rosas (2018). Essa visão de grandiosidade do país era difundida nas colônias. Todavia, a chegada a Portugal foi um choque para muitos retornados que nunca haviam estado lá e que esperavam encontrar um lugar que realmente contemplasse toda a grandiosidade pregada e reafirmada nos discursos do Estado Novo: "Portugal não era um país pequeno, era o que estava escrito no mapa da escola [...]. A metrópole não pode ser como hoje a vimos no caminho que o táxi fez, ninguém nos ia obrigar a cantar hinos aos sábados de manhã se a metrópole fosse tão acanhada e suja [...]" (CARDOSO, 2013, p. 83); ou ainda:

\footnotetext{
A metrópole era suja, feia, pálida, gelada. Os portugueses da metrópole eram pequeninos de ideias, tão pequeninos e estúpidos e atrasados e alcoviteiros. Feios, cheios de cieiro, e pele de galinha, as extremidades do corpo rebentadas de frio e excesso de toucinho com couves. Que triste gente! (FIGUEIREDO, 2019, p. 157).
}

Havia, portanto, um sentimento de frustração dos retornados em relação a Portugal e à sociedade portuguesa, o que dificultou ainda mais o processo de integração nesse novo espaço, gerando infelicidade e amargura, como constatamos na fala de Rui, irmão de Carlos: "penso no 
que aconteceria se tomasse todos os comprimidos de dormir do móvel com três portinhas em espelho da casa de banho" (ANTUNES, 1999, p. 328).

Somado às dificuldades de conseguir emprego e moradia, relacionadas mais propriamente a questões econômicas, havia ainda o preconceito: "As desconfianças em relação à multidão de intrusos eram enormes e não só devido a assuntos laborais: quem cá estava estranhava o sotaque, as roupas, a abertura de espírito e até os hábitos culturais de quem chegava" (GARCIA, 2012, n.p). Nesse sentido, os retornados saíram de África para fugirem da violência da guerra e, ao chegarem em Portugal, ao contrário do que imaginaram - um lugar seguro para recomeçarem suas vidas -, iniciam uma luta para conseguir se integrar nesse novo espaço. A narradora de Caderno de memórias coloniais era alvo de discursos ofensivos: "Em Portugal, habituei-me cedo a ser alvo de troça ou de ridículo, por ser retornada ou me vestir de vermelho ou lilás" (FIGUEIREDO, 2019, p. 137). Rui, em O retorno, era tratado de maneira diferente pela professora por ser retornado: "A puta da professora, um dos retornados que responda, como se não tivéssemos nome, como se já não bastasse ter-nos arrumado numa fila só para retornados. A puta a justificar-se, os retornados estão mais atrasados, sim, sim, devemos estar [...]" (CARDOSO, 2013, p. 139-140).

E Carlos, em $O$ esplendor de Portugal, sente-se explorado no trabalho: “[...] era a mim não à minha irmã que eu achava desgraçada, a contar tostões ansiosos do princípio ao fim do mês longe da Baixa do Cassanje, [...]" (ANTUNES, 1999, p. 71). Nesse contexto, como destaca Boaventura de Sousa Santos (2008), é possível problematizar que o colonialismo, mesmo depois de ter acabado, permanece, dentre outros aspectos, nas relações sociais, e, nesse sentido, é relevante perceber como a literatura desse contexto se transforma em um espaço para questionar as memórias produzidas sobre os processos de colonização e descolonização, bem como sobre a Guerra Colonial e suas consequências. Desse modo, a literatura abriu espaço para que "a questão saísse do espelho político-administrativo, onde as decisões eram tomadas, e do espaço doméstico, onde as famílias velavam seus mortos" (FRANCO, 2019, p. 71). Assim, esse período pode ser entendido e analisado de forma mais ampla, de modo a considerar outras perspectivas e discursos - não os tão difundidos pelo Estado Novo português -, como a visão dos retornados.

\section{Conclusão}

Ao considerar a produção literária portuguesa pós-25 de abril nos termos apontados por Miguel Real e João Barrento no início deste artigo, mas também ao dividi-la em dois momentos, é possível perceber como o passado recente da história de Portugal é introduzido num cenário de debate ainda relevante e atual. O trabalho de consciência, que segundo Eduardo Lourenço não foi realizado, surge na literatura que se volta para o real, não meramente como revisitação de um passado problemático e silenciado, mas principalmente por entender o quanto desse real ainda está presente na sociedade portuguesa, não apenas como herança, mas como prática social de um silenciamento que se mantém, por exemplo, sobre o racismo, sobre a presença africana, sobre um império que talvez nunca tenha existido. 
Ao analisarmos obras publicadas entre 1979 e 2012, percebemos como a preocupação inicial com a representação da Guerra Colonial se desdobra na necessidade de problematização da migração protagonizada pelos retornados, sintoma do declínio final do processo colonial, talvez mais que a Guerra em si. Os quatro primeiros romances representam, sob um olhar memorialístico e testemunhal, as dificuldades e as angústias enfrentadas. Essas obras expressam as fragmentações físicas e psíquicas do ambiente de tensão e de combate, que afetaram tanto os soldados portugueses quanto a sociedade dos espaços onde ele ocorria. Já os romances que se inserem em um segundo momento apresentam uma mudança de cenários se comparados aos quatro primeiros. O foco não é mais o ambiente de Guerra Colonial propriamente dita, mas transita entre o processo caótico de saída dos personagens de África e seu estabelecimento em Portugal. As tensões giram em torno do medo da violência, das incertezas relativas à chegada na ex-metrópole e das dificuldades enfrentadas nesse decurso.

Se a literatura portuguesa contemporânea não pode ser considerada uma "rua principal", como afirmou João Barrento, tampouco podemos dizer que as abordagens sobre o recente passado vivenciado no século XX se configuram como "rua principal". A África está lá como um referente, o Estado Novo, a Guerra, a Revolução, a descolonização... No entanto, esse referente real e brutal vem sendo absorvido e recriado de formas variadas, atravessando gerações de escritores, permitindo que os leitores façam o exame de consciência, talvez tão precariamente realizado pela sociedade em sentido amplo, sobre o que significou o pretenso império português.

\section{REFERÊNCIAS}

ALEGRE, Manuel. Jornada de África. Lisboa: Dom Quixote, 1989.

ANTUNES, António Lobo. O esplendor de Portugal. Rio de Janeiro: Rocco, 1999.

ANTUNES, António Lobo. Os Cus de Judas. 2. ed. Rio de Janeiro: Objetiva, 2010.

BARRENTO, João. A chama e as cinzas. Um quarto de século de literatura portuguesa (1974-2000). Lisboa: Bertrand Editora, 2016.

BENJAMIN, Walter. Magia e técnica, arte e política: ensaios sobre literatura e história da cultura. Tradução por Sérgio Paulo Rouanet. São Paulo: Brasiliense, 2012.

CARDOSO, Dulce Maria. O retorno. Rio de Janeiro: Tinta da China, 2013.

FIGUEIREDO, Isabela. Caderno de memórias coloniais. São Paulo: Todavia, 2019.

FRANCO, Roberta Guimarães. Portugalidade e pós-memória: configurações e desconstrução da identidade portuguesa no século XXI. In: CAMPOS, L. B.; CARRIZO, S.; MAGALHÃES, P. A. (Org.). (Pós-)Memória e transmissão na literatura contemporânea. Rio de Janeiro: ABRALIC, 2018, p. 153-166.

FRANCO, Roberta Guimarães. Memórias em trânsito: deslocamentos distópicos em três romances pós-coloniais. São Paulo: Alameda, 2019.

GARCIA, Rita. S.O.S. Angola. Alfragide: Oficina do Livro, 2011. E-book. ISBN: 9789895558636. Não paginado. 
GARCIA, Rita. Os que vieram de África: o drama da nova vida das famílias chegadas do ultramar. Alfragide: Oficina do Livro, 2012. E-book. ISBN: 9789895560110. Não paginado.

JORGE, Lídia. A Costa dos Murmúrios. Rio de Janeiro: Record, 2004.

LOURENÇO, Eduardo. O labirinto da saudade. Rio de Janeiro: Tinta da China, 2016.

MELO, João de. Autópsia de um mar de ruínas. Lisboa: Assírio e Alvim, 1984.

PIMENTA, Fernando Tavares. Causas do êxodo das minorias brancas na África portuguesa: Angola e Moçambique (1974/1975). Revista Portuguesa de História. Imprensa da Universidade de Coimbra, v. 48, p. 99-124, 2017.

REAL, Miguel. O romance português contemporâneo (1950-2010). Lisboa: Caminho, 2012.

RIBEIRO, Margarida Calafate. Percursos africanos: a Guerra Colonial na Literatura Pós-25 de Abril. Portuguese Literary \& Cultural Studies, n. 1, p. 125-152, 1998.

RIBEIRO, Margarida Calafate. Uma História de Regressos: Império, Guerra Colonial e Pós-Colonialismo. Coimbra: Oficina do CES, v. 188, p. 1-40, 2003.

RIBEIRO, Margarida Calafate. África no feminino: as mulheres portuguesas e a Guerra Colonial. Revista Crítica de Ciências Sociais, n. 68, p. 7-29, 2004.

ROSAS, Fernando. Salazar e o poder. A arte de saber durar. Lisboa: Tinta da China, 2018.

SANTOS, Boaventura de Sousa. Do pós-moderno ao pós-colonial. E para além de um e de outro. Travessias, n. 6/7, p. 15-36, 2008.

SELIGMANN-SILVA, Márcio. Narrar o trauma: a questão dos testemunhos de catástrofes históricas. Psicologia Clínica, v. 20, n. 1, p. 65-82, 2008. 